\title{
Change in the Population Structure in Finland ${ }^{1}$
}

\author{
ELLI KARJALAINEN
}

Acting Senior Research Associate

Research Institute of Northern Finland

Unit of Kainuu

University of Oulu

Kajaani, Finland

\begin{abstract}
On an international scale, the number of aged people ( 65 years and older) in Finland is still relatively low but showing rapid increase. The primary reason is the strong decrease of fertility which leads to a decline in the share of the younger age groups. As the average life expectancy is on the increase, this will further contribute to the growing share of the aged population. Migration affects considerably the regional population structures: selective migration has distorted the age and sex structures especially in the rural areas. Population aging bring on new challenges in community planning and social policy.
\end{abstract}

Keywords: aging, fertility decline, migration, Finland

\section{Population aging}

Population has become younger or older, depending on shifts in the proportions of people at various age levels. Thus roughly, during periods when relatively large numbers of children are being born but few people live to older ages, the median age of the population will fall. Conversely, in periods when relatively few children are being born but large numbers of people are reaching older ages, the median age will rise.

United Nations classifies the world's populations into three categories: "old" populations, where over $7 \%$ of the total population are over 65 -year-olds; "mature", with over 65 -year-olds constituting 4-7\% of the total; and "young" populations where this figure is under $4 \%$. Old populations are typically found in the highly developed industrialized nations, while young populations are characteristic of the developing countries (Hervonen and Pohjalainen 1991, 40).

The aging of population has become an essential problem in industrialized countries (see Knapp, Ross and McCrae 1989, 39-40; Kimmel 1990, 468-469). On an international scale, the number of aged people (65 years or older) in Finland is still relatively low but showing rapid increase. The primary reason is the strong decrease of fertility which leads to a decline in the share of the younger age groups. The conse-

\footnotetext{
1 The article is based on a contributed paper presented in the International Population Conference

"Revival of Ageing Societies" September 2-4, 1992 Espoo, Finland
} 
F i g u r e 1. Population pyramids in Finland, years 1950, 1985, 2000 and 2050.

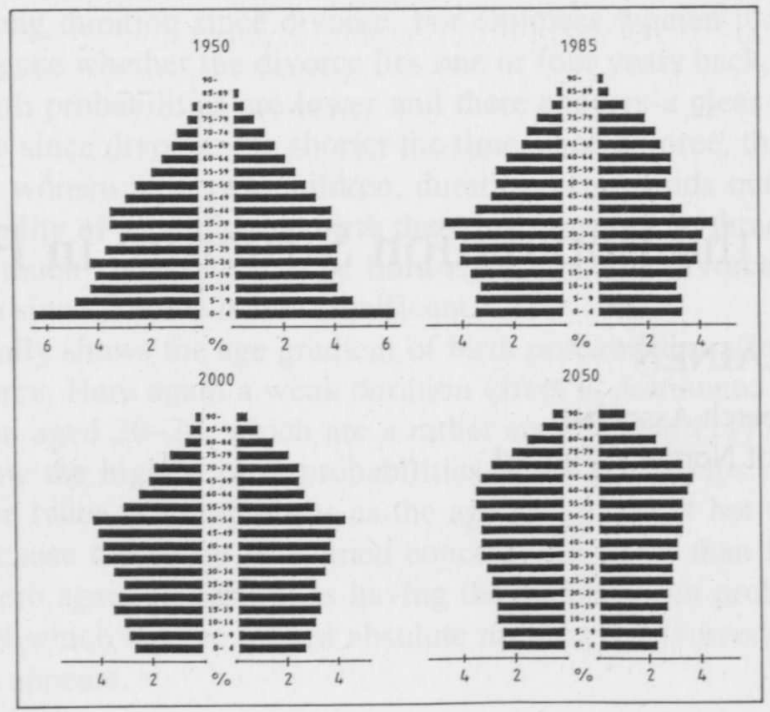

Source: Nikander 1987, 25

quences of this trend emerge first and foremost as a change in the relative amounts of children and aged people in the total population (Figure 1). As the average life expectancy is also on the increase, this will further contribute to the growing share of the aged population (Naukkarinen 1981, 14; Taloudellinen suunnittelukeskus 1986, 3; Hirstiö-Snellman 1990, 17).

As yet, the aging of population in Finland has not been as pronounced as in the other Nordic countries. 65-year-olds and older represent $13 \%$ of the Finnish population, while in 1988 the corresponding figures were $15.5 \%$ in Denmark, $16 \%$ in Norway, and nearly $18 \%$ in Sweden (SYF 1990, 479; Hervonen and Pohjalainen 1991, 40).

The number of Finnish people aged 65 years or over is constantly rising, while the other Nordic countries show some levelling or even downward trend. A sharp increase in the aged population is projected for the turn of the 21 st century, when the baby-boom cohorts begin to retire. A feature shared by all Nordic countries is the growing share of the "oldest old" age groups, illustrated by the following Finnish example: in 1970 , some $30 \%$ of the age group of 65 years or over were at least 75 years old $(125,300$ people), and in 1989 this figure was $42 \%(279,150)$. In other words: in less than 20 years the number of people living to the age of 75 or above had doubled. According to projections, by 2050 the share of 75 -year-olds and older of the aged population (65 years or over) will be $48 \%$ ( 465,000 people) (Nikander 1987, 24). In the Nordic countries the share of over 85 -year-olds in the over 75 -year old populaticn is estimated to rise from the present $15-20 \%$ to $25-29 \%$ by the year 2010 . This trend has powerful implications for the planning of senior citizens' services (Taloudellinen suunnittelukeskus 1986, 16; Valkonen and Nikander 1987, 12; Lindgren 1990, 10).

The world's most rapidly aging population is found in Japan. The pace of the aging development is apparent in the following projection: an increase from $10 \%$ to $20 \%$ in the share of over 65-year-olds is expected to take only 24 years in Japan (from 1985 to 2009); in Finland, which stands second in these statistics, this change is projected to take place in 48 years (from 1973 to 2021); and in Sweden it will take as much as 85 years (from 1929 to 2014) (Hervonen and Pohjalainen 1991, 41). 
F i g u r e 2. Fertility and mortality in Finland in 1881-1985 and their projection until 2025. (1) Births, (2) deaths, (3) excess of births over deaths, (4) excess of deaths over births (per thousand of population)

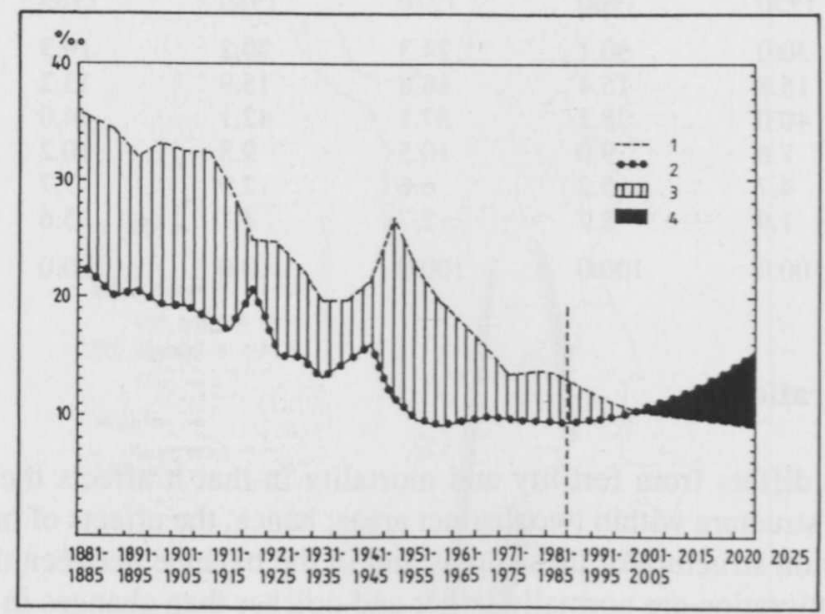

Source: Auvinen 1987, 6

\section{Low fertility}

In Finland the fertility rate has been declining over a long time span. Immediately after World War II an exceptional rise in fertility produced the "baby-boom cohorts"; but over the past twenty years the reproduction rate of population has been below 1 (approximately 0.8 ). The present Finnish population of 5.0 million will grow until the year 2001 according to population forecasts based on the present birth rate and death rate, but after that the population will again begin to decrease as the death rate comes to exceed the birth rate (Figure 2).

The variations of fertility have been significantly influenced by the values attached to family size. Even in rural Finland the traditional large families already belong to history; the rural population has effectively adopted the attitudes of the urban population towards family planning. The average child count per family is 1.7 , in the Helsinki metropolitan area only 1.3 . Nowadays a three-children family is a rarity, a "large family". The highest regional birth rate is found in the province of Oulu.

Decrease of population due to low fertility has also occurred in the other European countries where industrialization took place earlier than in Finland, and in many countries the total rate of reproduction per woman has fallen to the level 1.3-1.4. More favorable development has been achieved for example in France through intensive family policy (Auvinen 1987, 7).

In Finland the decline in fertility has rapidly increased the share of aged population. In 1960 the share of 65 -year-olds and over was about $7 \%$ of the total population (Table 1); by the latest information from the year 1991 this figure had risen to about $13.6 \%$, as $10 \%$ of the male population and $17 \%$ of the female population had reached this age. The continuing increase in the aged cohorts is partially caused by the fact that in Finland the demographic transition took place rather late, for instance in comparison to the other Nordic countries (Lutz 1987, 26; Valkonen and Nikander 1987, 17-18). 
T a b l e 1. Development of population structure in Finland 1950-89.

Age

$\begin{array}{lrrrrrr} & 1950 & 1960 & 1970 & 1980 & 1989 & 1950-89 \\ 0-14 & 30.0 & 30.1 & 24.3 & 20.2 & 19.3 & -20.4 \\ 15-24 & 15.8 & 15.4 & 18.8 & 15.9 & 13.2 & +2.5 \\ 25-54 & 40.0 & 38.1 & 37.1 & 42.1 & 44.0 & +36.0 \\ 55-64 & 7.6 & 9.0 & 10.5 & 9.8 & 10.2 & +65.3 \\ 65-74 & 4.7 & 5.2 & 6.6 & 7.9 & 7.7 & +103.9 \\ 75+ & 1.9 & 2.2 & 2.7 & 4.1 & 5.6 & +252.5 \\ \text { Total } & 100.0 & 100.0 & 100.0 & 100.0 & 100.0 & \end{array}$

\section{Effect of migration}

Migration differs from fertility and mortality in that it affects the population and the age-group structure within two distinct areas; hence, the effects of migration emerge in the population structure of these areas and in the balance between them. Moreover, variations in migration are normally larger and quicker than changes in fertility or mortality (see Lewis 1982, 1, 172). In the industrialized countries migration has particular significance for regional development, as the natural reproduction of population is in these countries on a considerably lower level than in the developing countries (Masser 1983, 241).

Regional population trends in Finland have been unbalanced since the Second World War essentially due to migration. The principal flows of migration have been from rural to urban areas, and from the sparsely populated countryside towards population centers. This trend has drawn population towards the southern and south-western parts of Finland (Figure 3). The effects of internal migration have been complemented by emigration to Sweden which reached its peak at the turn of the 1960s and 1970s when particularly Northern Finland suffered a considerable population loss (Majava 1981, 10). Regional development was somewhat balanced in the 1970 s (e.g. Talvitie 1982, 222), while the last decade was again a period of "neo-migration" from north to south and towards the regional centres (Karjalainen 1989, 74). The current economic recession has reduced the regional mobility of the population (see Relander 1982, 118, 126).

Especially from the point of view of rural areas, migration within municipalities has been imbalanced as the prevailing trend has been from rural areas towards builtup areas. This migration is among the principal factors affecting the regional structure: two thirds of all migration takes place within municipalities (Paasivirta 1981, 13; Valtioneuvoston kanslia 1983, 20). Also in the rural municipalities of Kainuu the effects of this migration have been observed: during the period 1980-85 it has meant a population loss of some 3,000 people from the rural areas, whereas migration between municipalities only amounted to roughly 1,800 people (Karjalainen 1989, 74).

Migration affects considerably the regional population structures. In the net loss migration areas both internal migration and emigration have reduced the working and reproducing population, as two thirds of the migrants come from the age group 15-34 years (see Myrskylä 1978, 22-23). Especially the southernmost province of Uusimaa has received positive migration balance in the mobile-active age group of 15-24 years, while the highest migration loss in this age group has been suffered by the province of Oulu (Table 2). Furthermore, migration weakens the marriage opportunities of the remaining population, as the majority of the migrants are women. This is a typically rural problem, as male-dominated population is characteristic of the rural areas (Karjalainen 1989, 22-23). 
F i g u r e 3. Principal migration flows between provinces of Finland, 1989.

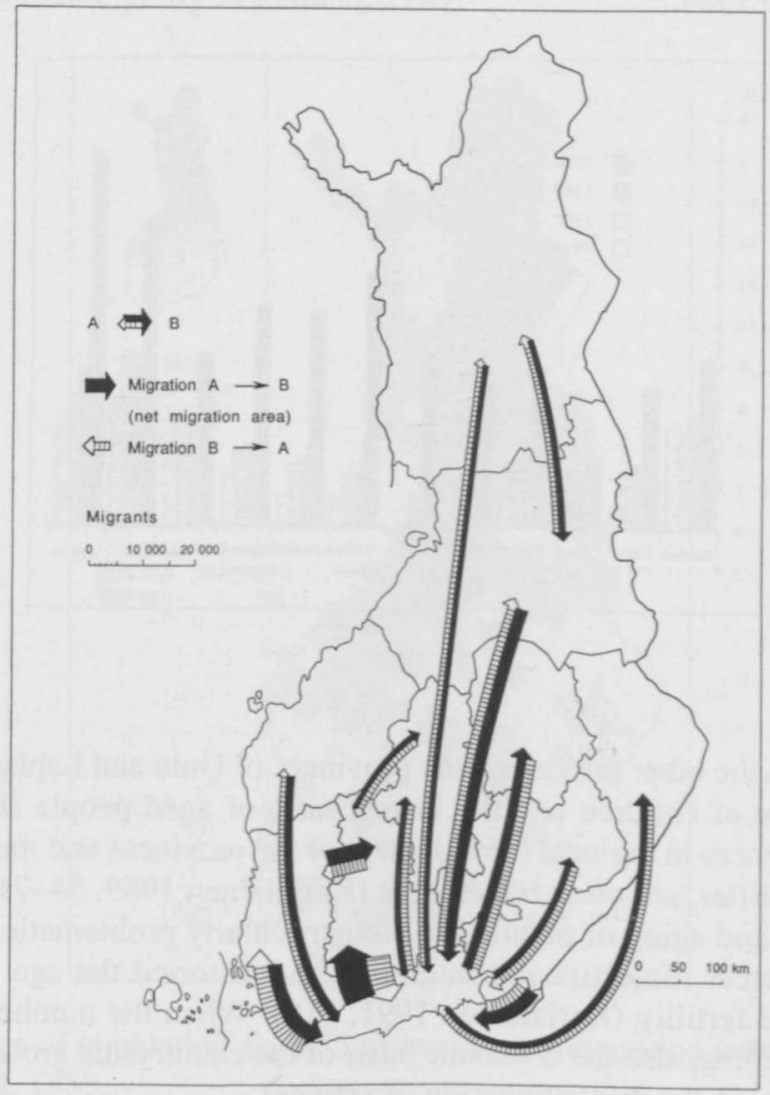

$\mathrm{T}$ a b l e 2. Balance of internal migration according to age group and province in Finland, 1988.

\begin{tabular}{lrrrrrr}
\multicolumn{7}{c}{ Migration balance } \\
Provinces & $0-14$ & $15-24$ & $25-54$ & $55-64$ & $65+$ & Total \\
Uusimaa & -1109 & 5761 & 1320 & -683 & -291 & 4998 \\
Turku \& Pori & 150 & -239 & -215 & 155 & 105 & -44 \\
Åland & 6 & 53 & 27 & 6 & -6 & 86 \\
Häme & 402 & 177 & 890 & 203 & 63 & 1735 \\
Kymi & 124 & -944 & -434 & 34 & 3 & -1217 \\
Mikkeli & 283 & -636 & 101 & 143 & 52 & -57 \\
Northern Karelia & 26 & -603 & -251 & 34 & 33 & -761 \\
Kuopio & 57 & -393 & -117 & 43 & 40 & -370 \\
Central Finland & 276 & -309 & 392 & 55 & -1 & 413 \\
Vaasa & -58 & -997 & -709 & 15 & 16 & -1733 \\
Oulu & -81 & -1119 & -553 & 31 & -2 & -1724 \\
Lapland & -76 & -751 & -451 & -36 & -12 & -1326
\end{tabular}

\section{Regional differentiation}

Even though Northern Finland has suffered net out-migration, fertility has remained rather high (Figure 4). This has been promoted by the favorable population structure: 
F i g u r e 4. Natural population increase by province in Finland in 1960, 1970, 1980 and 1989.

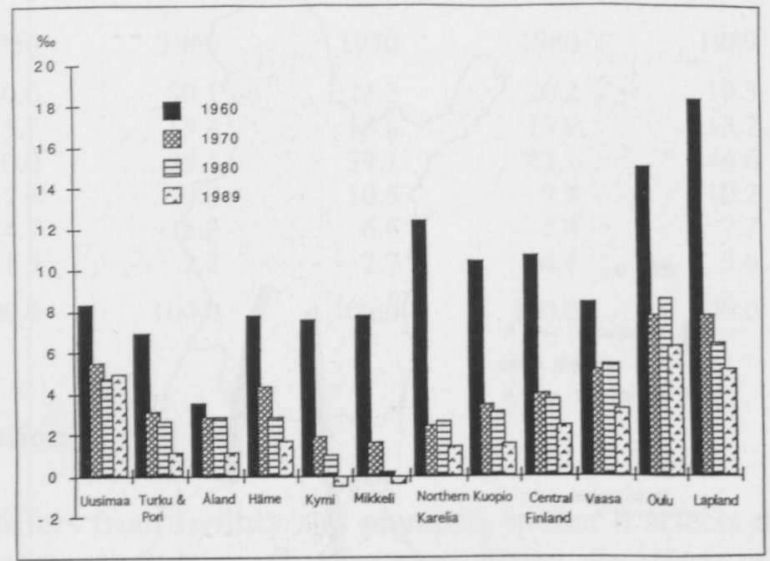

in comparison to the other provinces, the provinces of Oulu and Lapland have the highest relative share of children and the lowest ratio of aged people (Figures 5 and 6). However, differences in regional development of the provinces and municipalities, even within municipalities, are often remarkable (Karjalainen 1989, 54-71).

The decline and aging of population are particularly problematic phenomena with regard to rural areas. Selective out-migration has distorted the age and sex distribution and reduced fertility (Karjalainen 1991, 118). When the numbers of active rural population are falling, also the economic basis of the countryside grows narrower which frequently results in the discontinuation of services.

Despite the negative long-term population growth in the rural areas, some signs of a possible "new rise" in rural development have surfaced (e.g. Hautamäki 1984, 86-89). These have been explained by the changes taking place in the people's attitudes and values: the quality of life is increasingly valued, and in this respect the rural areas are in many ways better off than towns. Particularly the environmental factors have taken a new significance (e.g. Lewis 1982, 177-178).

The rural municipalities of Kainuu have also shown signs of increasing migration into rural surroundings. This has, however, not brought about any resettlement of the vast rural areas; instead the migration has been limited within a reasonable daily travel distance from the main built-up areas (Karjalainen 1989, 75). We can thus speak of the expansion effects of migration, while reduction remains typical of the peripheric areas (see Lloyd and Dicken 1977, 414-415).

\section{New challenges}

The low birth rate in post-industrialized societies presents new challenges for community planning and social policy. The decrease in population and distortion of its age structure are serious social problems, as the population forms the basis for all social activities (Auvinen 1987, 5-8). The age structure of a population is an important indicator of its balanced development, and can have a considerable effect on the economy of the municipalities and the use made of different services. A special problem in Finland is caused by the large age groups born during the post-war baby boom. Once 
F i g u r e 5. Share of population aged 0-14 years of the total population by province and municipality in Finland, 1989.

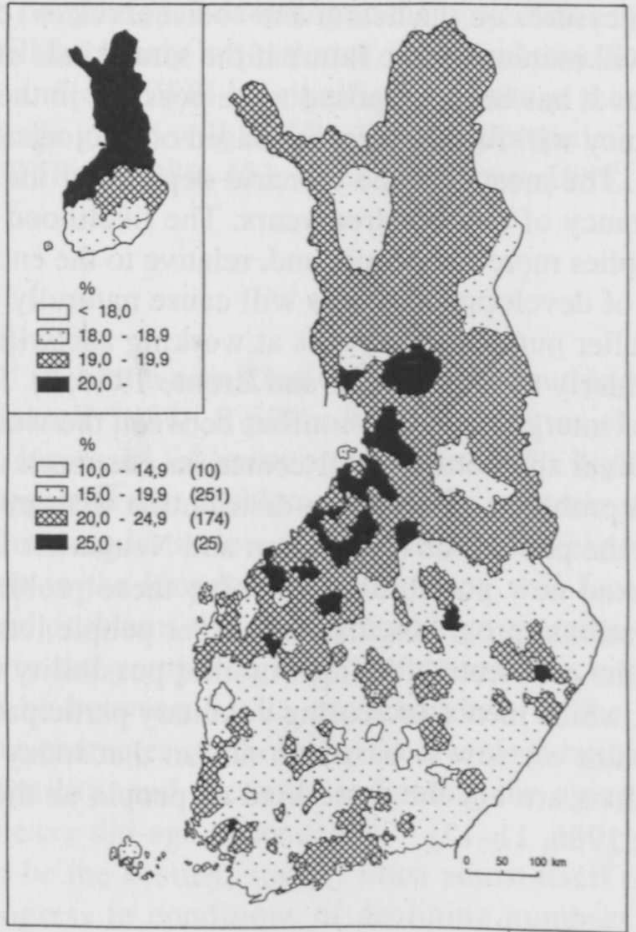

F i g u r e 6. Share of population aged 75 or over by province and municipality in Finland, 1989.

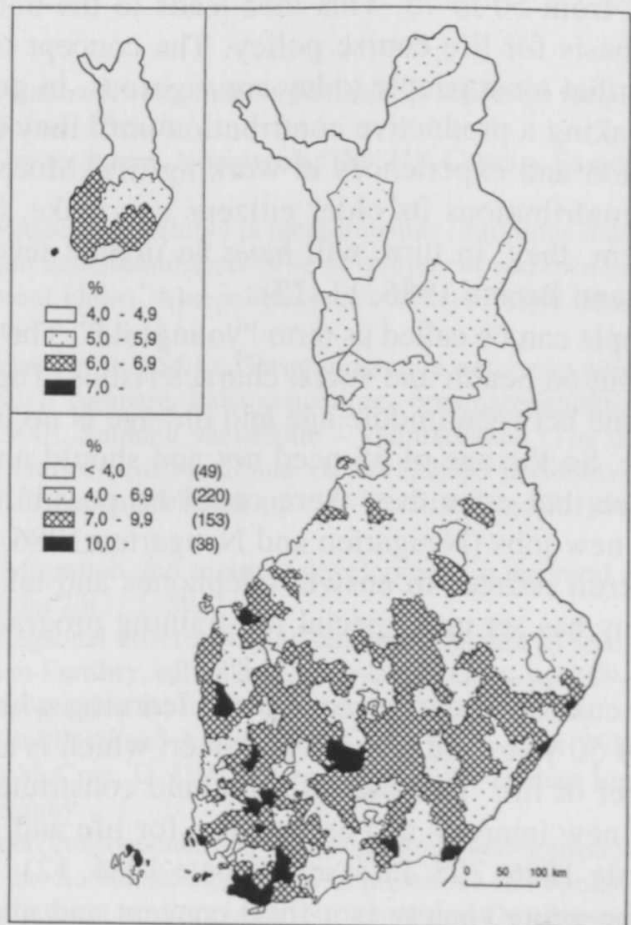


they had passed school age many municipalities had to close their schools. Nowadays these large age groups are part of the working population, but soon after the year 2000 they will begin to retire. The number of pensioners will then increase markedly, placing considerable pressures on the health and social services (cf. Lutz 1987, 29).

Population aging will increase in the future if the same kinds of development trends will occur in Finland as it has been supposed to be possible in the USA. According to trends the life expectancy will further increase based on socioeconomic developments and medical advances. The most extreme scenario depicts for the year 2050 a population with a life expectancy of one hundred years. The likelihood of continued low or even lower fertility implies more old people and, relative to the entire population, fewer children. These kinds of development trends will cause naturally new problems to the society, because a smaller number of persons at working age will be available to provide the services the elderly need (see Pifer and Bronte 1986, 7). People are concerned about the possibility of intergenerational conflict between the working-age population and the retired. They fear the conflict will center on economic issues. So the aging society does face real problems of resource distribution that are complicated by demographic changes in the population (Neugarten and Neugarten 1986, 42-43).

It has been presented new possibilities to solve these problems. One alternative may be found in educational programs that help older people learn skills for self-sufficiency to cope with the problems of aging. Another possibility could be the productivity of older citizens, which means increasing voluntary participation of elderly people to labor force. This point of view is based on notion that today's and especially future's elderly populations are not the same kind of people as the elderly of previous eras (Pifer and Bronte 1986, 11-12).

\section{"Third quarter of life"}

It has been proposed a new concept that embodies the new situation: "third quarter of life" - the years from 50 to 75 . This idea leads to the notion that age 65 has become obsolete as a basis for life-course policy. The concept is determined by the readily observable fact that most people today are vigorous, in good health, mentally alert, and capable of making a productive contribution until they are at least 75 . They have also good education and experiences in working life. More and more an aging society will need the contributions its older citizens can make, and, with long lives stretching ahead of them, they, in turn, will have an urgent need to stay productive (Pifer 1986, 402; Pifer and Bronte 1986, 11-12).

This part of old people can be called as term "young-old". The concept is not based on chronological age, but on health and social characteristics. The term represents the social reality that the line between middle age and old age is no longer clear now and especially in the future. So the age of 65 need not and should not be a time of withdrawal from labor force, but even then there could be possibilities for example to retrain old people into new jobs (Neugarten and Neugarten 1986, 35). Some hotels in the USA even now recruit retirees to answer telephones and take reservations. Also one hamburger company has set up a special job-training program for senior citizens (Beck 1990, 68).

More extensive discussion about retraining and learning whole a new career has happened in the case of 50 years old persons and over, which is also the lower part of the concept third quarter of life. This part of life could constitute a period of rebirth, with the awakening of new interests and enthusiasm for life and new possibilities for being productive (Moody 1986, 205; Pifer and Bronte 1986, 12).

Thus, old age in the aging society is a fluid concept and above all in the future 
when the population structure becomes older the importance of the old people in the labor force will increase. A significant proportion of the population, about $20 \%$, falls within the third quarter today in the USA and by the year 2010 the proportion will be close to a third of the population. According to the projections the proportion of people 65 years and over will be nearly a quarter of the population in 2035. The growth of the elderly 75 years and over will be significant, because there are estimations that the proportion of the age group will be $7 \%$ of the total population in 2010 in the USA and even 14\% in 2030 (Pifer 1986, 403; Pifer and Bronte 1986, 4).

\section{Finally}

It is interesting to present a new kind of thinking about population decline (Kono 1988; Macura and Malacic 1987). It offers benefits in terms of lower densities, environmental protection, increased longevity and wisdom and a higher quality of the population. It has been suggested that problems should be considered in a new light of the experience gained after decades of low fertility, higher life expectancies and aging.

"Once people step in the kingdom of aging, they will face entirely different dimensions of issues and problems which they could not imagine when they were in the domain of high fertility and youth-dominant population. It is not too exaggerating that humankind seems to be between Scylla and Charybdis in the whirlpooling strait of population, the former character symbolizing the overpopulation and heavy youth-dependency due high fertility, and the latter indicating the aging of population due to fertility decline and heavy old-age dependency."

If Charybdis is to be the destiny, society must adjust itself to make survival possible and continue progress in conditions of declining numbers and more old people (Macura and Malacic 1987, 40-41).

\section{References}

Auvinen, R. (1987). Population development in Finland - a challenge for planning? Yearbook of Population Research in Finland 25:5-8.

Beck, M. (1990). The Geezer boom. Newsweek, The 21st Century Family, Special Edition, pp. $62-$ 68.

Hautamäki, L. (1984). Maaseudun kehitys ja omatoimisuus : tutkimus maaseudun kehitystekijöistä ja uuden kehittämislinjan hahmottamisesta (The development and own initiative of rural areas : outlining new development ideas). Aluepoliittisia selvityksiä I:1984. Helsinki: Sisäasiainministeriö, Aluepoliittinen osasto.

Hervonen, A. and Pohjalainen, P. (1991). Gerontologian ja geriatrian perusteet (Introduction to gerontology and geriatrics). Tampere: Lääketieteellinen oppimateriaalikustantamo.

Hirstiö-Snellman, P. (1990). Suomen väestökato - valintatilanne (The decrease of Finnish population - a situation of choice). In: Maailman väestöräjähdys ja Suomi (The world population explosion), edited by Ulrica Gabrielsson, pp. 16-26, Julkaisuja 2/1990. Helsinki: Tutkijoiden ja kansanedustajien Seura.

Karjalainen, E. (1989). Migration and regional development in the rural communes of Kainuu, Finland in 1980-85. Nordia 23(1):1-89.

Karjalainen, E. (1991). Regional differences and temporal changes of fertility in Finland. In: The Geographical Approach to Fertility, edited by J. Bähr and P. Gans, pp. 109-119. Kieler Geographische Schriften 78. Kiel: Geographische Institut.

Kimmel, D.C. (1990). Adulthood and Aging. 3rd ed. New York: John Wiley \& Sons.

Knapp, B.; Ross, S. and McCrae, D. (1989). Challenge of the Human Environment. London: Longman Advanced Geography.

Kono, S. (1988). The social consequences of changing family and household structure associated with an aging population. In: Economic and Social Implications of Population Aging : Proceedings of the International Symposium on Population Structure and Development, Tokyo, 10-12 Septem- 
ber 1987, pp. 276-304. ST/ESA/SER.R/85. New York: United Nations.

Lewis, G.J. (1982). Human Migration. London.

Lindgren, J. (1990). Suomen väestö ennusteiden valossa (Finnish population in the light of projections). In: Suomalainen väestöruletti, pp. 7-17. Väestöliiton Kolmikantasarja 12. Helsinki: Väestöliitto.

Lloyd, P. and Dicken, P. (1977). Location in Space : A Theoretical Approach to Economic Geography. 2nd ed. London: Harper \& Row.

Lutz, W. (1987). Effects of fertility trends on population aging in Finland. Yearbook of Population Research in Finland 25:19-29.

Macura, M. and Malacic, J. (1987). Population Prospects for Europe. In: European Population Conference 1987, Jyväskylä, Finland, 11-16 June 1987, Plenaries, pp. 1-46. Helsinki: Central Statistical Office of Finland.

Majava, A. (1981). Pohjoismainen muuttoliike (Nordic migration). In: Atlas of Finland, Folio 210, Population, pp. 10-12. Helsinki: National Board of Survey and Geographical Society of Finland.

Masser, I. (1983). Planning and migration research. In: Population Movements: Their Forms and Functions in Urbanization and Development, edited by P. Morrison, pp. 241-260. Liege: IUSSP.

Moody, H. (1986). Education as a lifelong process. In: Our Aging Society: Paradox and Promise, edited by A. Pifer and L. Bronte, pp. 199-217. New York.

Myrskylä, P. (1978). Maassamuutto sekä Suomen ja Ruotsin välinen muuttoliike 1950-1975 (Internal migration and migration between Finland and Sweden in 1950-1975). Studies No. 48. Helsinki: Central Statistical Office of Finland.

Naukkarinen, Arvo (1981). Väestön rakenne. In: Atlas of Finland, Folio 210, Population, p. 14. Helsinki: National Board of Survey and National Geographical Society of Finland.

Neugarten, B. and Neugarten, D. (1986). Changing meanings of age in the aging society. In: Our Aging Society: Paradox and Promise, edited by A. Pifer and L. Bronte, pp. 33-51. New York.

Nikander, T. (1987). Väestö eilen, tänään, huomenna (Population in Finland, past, present, future). Helsinki: Tilastokeskus.

Paasivirta, Anssi (1981). Aluepolitiikan välitilinpäätös (Interim balancing of accounts of the regional policy). PTT-katsaus 2(1):12-24.

Pifer, A. (1986). The public policy response. In: Our Aging Society: Paradox and Promise, edited by A. Pifer and L. Bronte, pp. 391-413. New York.

Pifer, A. and Bronte, L. (1986). Introduction: squaring the pyramid. In: Our Aging Society, Paradox and Promise, edited by A. Pifer and L. Bronte, pp. 3-13. New York.

Relander, T. (1982). Tuottavuuden kehityksen ja maassamuuton väliset yhteydet (The connections between the development of productivity and internal migration). In: Muuttoliikesymposium 1980, edited by O. Koivukangas, K. Lindström and R. Narjus, pp. 117-127. Siirtolaisuustutkimuksia A 8. Turku: Siirtolaisuusinstituutti.

SYF $=$ Suomen Tilastollinen Vuosikirja (Statistical Yearbook of Finland) 1990 (1990). Helsinki: Central Statistical Office of Finland.

Taloudellinen suunnittelukeskus (1986). Harmaantuva Suomi 2030? (Greying Finland in 2030?). Helsinki.

Talvitie, J. (1982). Aluerakenteen kehittäminen ja palvelujen saavutettavuus maakuntatasolla (The developing of regional structure and reachability of services at province level). In: Muuttoliikesymposium 1980, edited by O. Koivukangas, K. Lindström and R. Narjus, pp. 220-231. Siirtolaisuustutkimuksia A 8. Turku: Siirtolaisuusinstituutti.

Valkonen, T. and Nikander, T. (1987). Demographic changes in the aged populations of four Nordic countries. Yearbook of Population Research in Finland 25:9-18.

Valtioneuvoston kanslia (1983). Aluepoliittinen katsaus (Regional policy review). 1982/83. Helsinki. 